\title{
UKM Development Business Loan
}

\author{
Muh. Barid Nizarudin Wajdi ${ }^{1}$, Yuli Choirul Ummah ${ }^{2}$, Devit Etikasari ${ }^{3}$ \\ ${ }^{123}$ STAI Miftahul Ula Nganjuk \\ baridnizar84@gmail.com
}

\begin{abstract}
Purpose : The aim for this paper is a) to identify the difficulties and problems faced by UKM in obtaining venture capital loans. b) Determining the strategy of development of UKM through increased ease of working capital credit facilities through credit channeling institution.

Design/methodology/approach : This type of research is exploratory. Types of data used are data collected by primary and save a list of questions.

Findings : The results are as follows: More than $50 \%$ of UKM have difficulty capital. UKM that utilize external capital sources of credit channeling institution only at $17.50 \%$. Reason UKM have not utilized most of the credit is a factor of the policies, terms and loan interest rates are quite high..

Research limitations/implications : Location of the research done on UMKM in the district of Nganjuk.

Practical implications : there are several strategies that can be done are (1) Optimizing the role KKMB in nurturing and mentoring the UKM prospect will apply for business loans, (2) promoting financing for results or venture capital, (3) enhance the role of credit guarantee institutions for UKM prospects will hit their collateral requirements. It is expected that with the implementation of the above strategies, the prospects of UKM no longer have difficulty in obtaining loans from the venture capital Credit Channeling Institutions.

Originality/value : UKM provide a significant contribution to employment, amounting to 99.6 percent. Meanwhile, the contribution of UKM to Gross Domestic Product (PDB) by 56.7 percent. In the process of economic recovery of Indonesia, the UMKM sector has a strategic role and importance that can be viewed from various aspects..
\end{abstract}

Paper type : Research paper

Keyword: UKM, UMKM, Development, Loan 


\section{INTRODUCTION}

Micro, small and medium enterprises (UMKM) are businesses engaged in various business sectors, which touch the interests of the community. Based on BPS data (2003), the population of small and medium enterprises (UMKM) amounted to 42.5 million units, or 99.9 percent of all businesses in the country. UKM provide a significant contribution to employment, amounting to 99.6 percent. Meanwhile, the contribution of UKM to Gross Domestic Product (PDB) by 56.7 percent.

In the process of economic recovery of Indonesia, the UMKM sector has a strategic role and importance that can be viewed from various aspects. First,a large number of industry and found in every sector of the economy. Based on data from the Central Statistics Agency (BPS) in 2002, the number of UKM recorded 41.36 million units or $99.9 \%$ of total business units. Second, its great potential in employment. Each investment unit in MUMKM sector can create more jobs than the same investment in large enterprises. MUMKM sector absorbs 76.55 million workers, or $99.5 \%$ of the total labor force that works. Thirdly, the contribution of UKM to PDB is quite significant, amounting to $55.3 \%$ of total PDB.

One effort to increase and development of UKM in the national economy is done by encouraging venture capital lending to MUKM. From the point of banking, lending to UKM profitable for the bank. The First, relatively small level of traffic jams. This is mainly due to the small business customer compliance level is higher than big business customers. Second, lending to UKM to encourage the spread of risk, for lending to small businesses with a nominal value of small loans allow banks to increase the number of customers, so that credit is not concentrated in one specific group or sector. Third, UMKM loans with a number of customers are relatively more will be able to diversify the loan portfolio and spread the risk of lending. Fourth, mortgage interest rates on 
Volume 1 Number 12017

This work is licensed under a Creative Commons Attribution-

ShareAlike 4.0 International License.

market interest rate for small businesses is not a major problem, allowing lenders to earn sufficient interest. Experience indicates that the availability of funds at the right time, in the right amount, the right target and with a simple procedure that is more important than the interest cost and subsidy.

However, some things that the background as mentioned above, is still not quite be the cornerstone belief that UKM will get the ease of filing of venture capital credit facility to the lending institutions both banking and non-banking. Until now there are many UKM are experiencing problems in terms of business credit application.

\section{PURPOSE OF WRITING}

The purpose of this paper include:

a) identify the difficulties and problems faced by UKM in obtaining venture capital loans.

b) Determining the strategy of development of UKM through increased ease of working capital credit facilities through credit channeling institution.

\section{MATERIAL AND METHOD}

The type of research conducted is Explanatory Research. This research type is chosen in order to build an analysis result that can function to explain, predict and control a symptom or relation between independent variable with dependent variable (Sugiyono, 2005: 56). In this study, the data used are primary and secondary data. Primary data is obtained from UKM The population in this study are the street UMKM and UKM, which number 30 in Nganjuk District Nganjuk Regency. And this study will use the total population because the amount is not too large.

The method of data analysis used in this research is by using method of 
quantitative analysis. Quantitative analysis method is a method performed on data in the form of numbers or numbers by collecting data, classifying data, explain, and analyze.

\section{RESULT AND DISCUSSION}

According to Sri Winarni (2006) In general, small businesses have the feature are as follows: (1) Usually the form of individual business and has not been incorporated company, (2) Aspects of the legality of a weak effort, (3) the organizational structure is simple with the division of labor is not standard, (4) Most do not have the financial statements and no separation between personal wealth with the wealth of the company, (5) management quality is low and seldom have a business plan, (6) the main sources of venture capital is private capital, (7) Human Resources (HR) limited, (7) the owners have a strong bond with the company, so that all the obligations of the company is also the duty of the owner.

The Central Bureau of Statistics (2003) in Sri Winarni (2006) identify common problems faced by UKM are: (1) Lack of capital, (2) difficulty in marketing, (3) Competition is tight, (4) Difficulty of raw materials, (5) Less production techniques and expertise, (6) Skills managerial less, (7) lack of knowledge of financial management, and (8) business climate less conducive (licensing, rules / regulations)

the result of research collaboration between the Ministry of State KUKM with BPS (2003) in in Sri Winarni (2006) informs that UKM are having difficulty business $72.47 \%$, the remaining $27.53 \%$ is no problem. $72.47 \%$ of the business is experiencing difficulties, identified difficulties that arise are: (1) Capital $51.09 \%$, (2) Marketing 34.72\%, (3) Raw materials 8.59\%, (4) Employment 1, 09\%, (5) $0.22 \%$ Distribution of transportation and (6) Other 3.93\%.

The dominant percentage difficulties facing UKM mainly include the difficulty of 
capital (51.09\%). It is further mentioned that in overcoming difficulties and capital known as much as $17.50 \%$ of UKM increase their capital by borrowing from the bank, the remaining $82.50 \%$ do not make loans to the bank but to the Non-bank institutions such as Credit Unions (KSP), individuals, families, capital venture, others.

While the problems faced by UKM in obtaining credit venture capital, among others: (1) The procedure which is difficult to $30.30 \%$, (2) Not interested in 25.34\%, (3) Actors UKM not have collateral 19.28\%, (4) UKM who do not know the procedure $14.33 \%$, (5) high interest rate $8.82 \%,,(6)$ the proposal was rejected (1.93\%).

According to Sri Winarti (2004) taking into account the important role of UKM in the various aspects of the economy and in an accelerated recovery of the economic activity, Bank Indonesia provides support in the development of UKM. Bank Indonesia support this as well in order to encourage the recovery of bank intermediation and creating a healthy banking conditions.

In order to support the empowerment and development of UKM especially in encouraging lending to MUKM, efforts by Bank Indonesia, among others through the implementation of credit policies, the provision of technical assistance to UKM through Financial Consultant Banking Partner, research on patterns of financing to UKM, the provision of financial information systems and small enterprises the provision of technical assistance.

\section{DISCUSSION}

Looking at the above explanation, it can be said that the difficulties faced by UKM in among others: (1) Lack of capital, (2) difficulty in marketing, (3) Competition is tight, (4) Difficulty of raw materials, (5) Less production and technical expertise, (6) lack of managerial skills, (7) lack of knowledge of financial management, and (8) the unfavorable business climate (licensing, 
rules / regulations).

While the fundamental problems commonly faced by UKM in obtaining venture capital is difficult because of the application procedure, the absence of collateral, ignorance of procedures and high interest rates. From some of the problems mentioned above, the internal problems are factors ignorance of the procedure, while other factors are is the external factor (the creditor).

When viewed from the side of creditors (financiers or financial institution), to protect the credit risk, requires the business activities undertaken by the principles of modern management, the official business license as well as a guarantee (collateral). Differences in perspective between the problems faced by UKM with the conditions that must be obeyed by credit channeling institution that is the fundamental reason why the UKM still have difficulty in obtaining working capital loans.

See policy and technical assistance of Bank Indonesia that already exist, then there are some efforts to be made in order to provide facilities for UKM in obtaining credit venture capital, among others:

\section{a. Optimizing the role of Bank Partner Financial Consultant (KKMB)}

Bank Partner Financial Consultant (KKMB) is part of the institution or institutions that provide business development services in order to improve the performance of Micro, Small and Medium Enterprises (UMKM). The agency is not legal entities and financial institutions as well as to collect a fee from its services. Services provided are consulting services in management / financial analysis enable the partnership with the bank or the distribution of funds to the UMKM bank. In this case, including assistance when preparing loan proposals, connect to the financial institution / bank and monitoring since the time of disbursement of credit to the appropriate credit repayment term of the agreement.

KKMB functions and responsibilities is to provide guidance and 
Volume 1 Number 12017

This work is licensed under a Creative Commons Attribution-

ShareAlike 4.0 International License.

development of MUKM. Coaching is meant here is an integral process in which includes three components, grow, maintain and elaborated. The process of implementation guidance by $\mathrm{KKMB}$ be participatory, that everything related to coaching (materials, methods, etc.) should always be based on the needs of UKM, therefore the working relationship between KKMB with UKM is not as superiors and subordinates or the relationship between the builder with the coached. The relationship is equal and KKMB here serve as a motivator for UKM.

Forms of activity here is the promotion and development assistance to UKM by providing technical assistance in the form of training as needed, referrals and consultations. To perform these activities a KKMB in their execution in the field based on the following steps:

1. Identify the prospective UMKM customers in the region / center / business population;

2. Determine if the group obtained micro prospective customers in order of efficiency;

3. Drafting a proposal for credit (micro-enterprise) or Feasibility businesses (UMKM);

4. The UMKM customers connect with the banks;

5. Monitoring and assisting the post-acceptance of credits is expected that the optimization of the role of $\mathrm{KKMB}$, requirements and procedures established by the Institute of loan portfolio, is no longer an obstacle for UKM in obtaining venture capital loans. The success of this approach will be seen from the increasing number of UKM are bankable and obtain working capital loans, and the inability to operate the business KKMB (mutual) so that it can finance itself 


\section{b. Socializing Pattern Sharing Financing or Venture Capital Funding}

For some UKM who feel burdened by high interest rates, the need for venture capital may be submitted to financial institutions that apply the pattern of cooperation with the outcome. Where the return is given UKM in accordance with the results obtained at the time of UKM so that UKM are not burdened with high interest rates. Financial institutions that apply the pattern of results is a Venture Capital Financing Company with the concept of a pure revenue sharing or for the results placement.

In terms of nature Characteristic Gain Venture Capital Risk (tend to be more willing to take risks), this financing has a looser procedures and prefer the prospects and potential of UKM in its development efforts. This financing can be done in the short term and long (up to 4 years).

Venture Capital Funding not only to channel funds from the shareholders and bank loans but also channeling funds government programs at a cheaper rate than the rate commercial loans. The program funds disbursed by venture capital companies, among others such as LPDB funds (Revolving Fund Management Institution) and the Partnership Fund (Community Development Partnership Program) from PT. Bahana Artha Ventura and LPEI (Indonesian Export Institute business)

Expected to socialization of venture capital financing, UKM have problems in terms of lending will still get credit in the form of venture capital financing cooperation pattern of results or credit LPDB and Partnership program.

\section{c. Increasing the participation of the Credit Guarantee Institution}

Another alternative that can be used to overcome the problems of MUMKM lending is credit guarantee scheme. In these schemes, the Bank and Guarantee Company made a loan guarantee agreement. UKM which 
need additional capital from channeling institutions submit credit guarantee to the Guarantee Company and applying for a loan to the Bank. If the results of the feasibility analysis, business as feasible (feasible), but it is not feasible from the standpoint of banks because of inadequate collateral (bankable),then the bank guarantee to the Guarantee Company filed. Furthermore Guarantee Company will conduct a feasibility analysis. If the loans are feasible for guaranteed, then the Company Guarantor will provide guarantees to small businesses that are expressed in the form of Certificate is Assurance. The guarantee given on the small businesses that are guaranteed to be paid to the guarantee fee Guarantee Company.

If the guaranteed credit congested, the Guarantee Company will check whether the existing conditions meet the terms and conditions agreed upon by the Company Guarantor and the Bank. When all the requirements have been met, then the Guarantee Company will make a payment claim. Furthermore, the Company Guarantor entitled to subrogation receivables for the portion of loans guaranteed. After payment of claims made, the Bank still have to collect until the debt is paid off. The results of that billing is divided proportionally between the Company Guarantor and the Bank in accordance with the percentage of credit guarantee. With the credit guara ntee, then:

1. Filing credit by small businesses that previously did not meet the banking requirements become bankable, so that UKM can develop their business.

2. Bank risk is reduced, as some have been transferred to the Company's risk Guarantor. With the fulfillment of the adequacy of collateral and reduced risk, then the likelihood of rejection of loan proposals become smaller.

3. Guarantee Company also conducts feasibility and control of credit guaranteed. With the presence and control of two different parties are 
Volume 1 Number 12017

This work is licensed under a Creative Commons Attribution-

ShareAlike 4.0 International License.

expected risk can be further minimized.

4. Guarantee Company will earn income fee guarantee.

Hopefully, by the credit guarantee scheme for UKM, then the UKM are experiencing problems in terms of collateral can be resolved because of the guarantee of the credit guarantee institutions. The channeling institutions credit will feel safe in extending credit to UKM.

\section{CONCLUSION}

UKM very dominant compared with other business scale. In addition, the role of small businesses in absorbing labor is relatively large. So that business development is a strategic step in improving public welfare and national economic growth. More than $50 \%$ of UKM have difficulty capital. UKM that utilize external capital sources of credit channeling institution only at $17.50 \%$. Reason UKM have not utilized most of the credit is a factor of the policies, terms and loan interest rates are quite high.

Therefore in order to further develop UKM, then there are several strategies that can be done are (1) Optimizing the role KKMB in nurturing and mentoring the UKM prospect will apply for business loans, (2) promoting financing for results or venture capital, (3) enhance the role of credit guarantee institutions for UKM prospects will hit their collateral requirements. It is expected that with the implementation of the above strategies, the prospects of UKM no longer have difficulty in obtaining loans from the venture capital Credit Channeling Institutions 


\section{REFERENCES}

Bustami, Bernadien, Sandra Nurlela \& Ferry. 2007. Mari Membangun Usaha Mandiri: Pedoman Praktis Bagi UKM, Yogyakarta: Penerbit Graha Ilmu.

Frinces, Heflin. (2004) Kewirausahaan dan Inovasi Bisnis, Cetakan Pertama, Yogyakarta: Pener-bit Darusalam.

Hills, Gerald. (2008) "Marketing and Entrepreneur-ship, Research Ideas and

Opportunities", Journal of Small and Medium Entrepreneur-ships, page: 27-39.

Jong \& Wennekers. (2008) "Conceptualizing Entre-preneurial Employee Behavior", SMEs and Entrepreneurship Programme Finance by the Netherlands Ministry of Economic Affairs.

Rahayu, Sri Lestari (2005) Analysis of Venture Capital Company Role In Developing UKM in Indonesia, Review of Economics and Finance, Bureau of Economic, Financial and International Cooperation.

Rencana Pembangunan Jangka Menengah Nasional (RPJMN). 2004,

Peraturan Presiden Republik Indonesia Nomor 7 Tahun 2005 tentang

Ren-cana Pembangunan Jangka Menengah Nasio-nal, Jakarta: Sinar Grafika.

Subari, Sri Mulyati Tri (2004) Policies and Strategies for Development of Bank Indonesia in Support of Sustainable Financial Services for Micro, Small and Medium Enterprises. Deputy Director of Rural Bank Supervision.

Sugiyono. 2005. Metode Penelitian Bisnis, Bandung: Alfabeta.

Suryana. 2003. Kewirausahaan, Pedoman Praktis, Kiat dan Proses Menunju

Sukses, Edisi Revisi, Jakarta: Salemba Empat.

Kementerian Negara Koperasi dan UKM. 2009. Undang-Undang Usaha Mikro

Kecil dan Menengah (UMKM) UU RI No.20 Tahun 2008, Jakarta: Sinar 
International Journal of Entrepreneurship and Business Development

Volume 1 Number 12017

This work is licensed under a Creative Commons Attribution-

ShareAlike 4.0 International License.

Grafika.

Yaghoobi, Salarzehi, Aramesh \& Akbari, 2010, "An Evaluation of Independent Entrepreneurship Obstacles in Industrial SMEs", European Journal of Social Sciences, pp. 33-45.

Winarni, Sri (2006) Small Business Development Strategies Through Increased accessibility of Banking Credit. Infokop No. 29 XXII 2006. 